\title{
Handgrip Strength is more associated with blood glucose than ACE and AGT polymorphisms in hemodialysus patients
}

\author{
A Força de preensão manual está mais associada à glicose no sangue do que os polimorfismos ECA \\ e AGT em pacientes em hemodiálise \\ Handgrip Strength está más asociada con la glucosa en sangre que los polimorfismos ECA y AGT
}

en pacientes con hemodiálisis

Received: 03/28/2021 | Reviewed: 04/03/2021 | Accept: 04/16/2021 | Published: 04/30/2021

Anderson Sola Haro

ORCID: https://orcid.org/ 0000-0001-8339-9894 Federal University of São Paulo, Brazil

E-mail: haro.sp@gmail.com

Thiago dos Santos Rosa

ORCID: https://orcid.org/ 0000-0003-0418-0945

Catholic University of Brasilia, Brazil

E-mail: thiagoacsdkp@yahoo.com.br

Hugo de Luca Corrêa

ORCID: https://orcid.org/0000-0002-3080-9391 Catholic University of Brasilia, Brazil

E-mail: hugo.efucb@gmail.com

Rodrigo Vanerson Passos Neves

ORCID: https://orcid.org/0000-0002-3257-7870

Catholic University of Brasilia, Brazil

E-mail: rpassosneves@yahoo.com.br

Michel Kendy Souza

ORCID: https://orcid.org/0000-0001-6421-5201

Federal University of São Paulo, Brazil

E-mail: mks_gtr@hotmail.com

Fernando Costa

ORCID: https://orcid.org/0000-0002-2346-3038

Federal University of São Paulo, Brazil

E-mail: jmc.focusnutrition@gmail.com

José Adeirton

ORCID: https://orcid.org/0000-0002-5637-9932

Clínics Home Dialysis Center and Renal Class Group, Brazil

E-mail: adeiron.ton@hotmail.com

Carmen-Tzanno Branco Martins

ORCID: https://orcid.org/0000-0002-7839-1828

Clínics Home Dialysis Center and Renal Class Group, Brazil

E-mail: tzanno@gmail.com

Luiz Henrique Peruchi

ORCID: https://orcid.org/0000-0001-9721-3886

Universidade de Mogi das Cruzes, Brazil

E-mail: peruchi10@gmail.com

Whitley Stone

ORCID: https://orcid.org/0000-0003-4984-141X

Western Kentucky University, United States

E-mail:whitley.stone@wku.edu

Jonato Prestes

ORCID: https://orcid.org/0000-0003-0399-8817 Catholic University of Brasilia, Brazil

E-mail: jonatop@gmail.com

Jéssica Mycaelle Silva Barbosa

ORCID: https://orcid.org/0000-0002-5421-9732

Catholic University of Brasilia, Brazil

E-mail: jessicamycaelle.nut@gmail.com

Sandro Soares de Almeida

ORCID: https://orcid.org/0000-0002-4392-0953

Federal University of São Paulo, Brazil

Hospital Israelita Albert Einstein, Brazil

E-mail: sanscientific@gmail.com 


\author{
Ronaldo Carvalho Araújo \\ ORCID: https://orcid.org/0000-0003-2211-2380 \\ Federal University of São Paulo, Brazil \\ E-mail: araujo.ronaldo@unifesp.br \\ Reury Frank Pereira Bacurau \\ ORCID: https://orcid.org/0000-0003-1777-294X \\ University of Sao Paulo, Brazil \\ E-mail: reurybacurau@usp.br
}

\begin{abstract}
Background: Patients with chronic kidney disease (CKD) often present with comorbidities like hypertension and diabetes. These conditions are often associated with loss of strength, which is a strong predictor of mortality. In this sense, it is reasonable to investigate genetic and physiological markers that could be related to strength and identify variables associated with this phenomenon. Objective: This study aimed to investigate the influence of angiotensin-1 converting enzyme (ACE) and angiotensinogen (AGT) M235T polymorphisms, and blood glucose on handgrip strength (HGS) for CKD patients with and without diabetes mellitus (DM). Methods: Male patients $(\mathrm{n}=84)$ participated in this cross-sectional study. Patients were grouped based on the diagnosis of DM or not. We evaluated HGS using a dynamometer and ACE and AGT polymorphism by polymerase chain reaction. Results: There were differences in HGS between groups. Follow up analyses indicated a difference in the distribution of ACE polymorphism alleles was associated with the reduction in HGS in the DM group. The same response was present for AGT. A negative correlation existed between blood glucose levels and HGS $(r=-0.334$ with $\mathrm{p}<0.05)$. Discussion: The present data suggests that there is a relationship between physical capacity and poor glycemic control. Conclusion: Our study demonstrated that blood glucose levels are associated with HGS in patients with CKD independent of ACE I/D and AGT M235T polymorphisms. Presence of DM may influence functional strength retention.
\end{abstract}

Keywords: Genetic polymorphism; Muscle strength; Diabetes Mellitus; Renin-Angiotensin system; Aging; Renal insufficiency, chronic.

\title{
Resumo
}

Introdução: Pacientes com doença renal crônica (DRC) freqüentemente apresentam comorbidades como hipertensão e diabetes. Essas condições costumam estar associadas à perda de força, que é um forte indicador de mortalidade. Nesse sentido, é razoável investigar marcadores genéticos e fisiológicos que possam estar relacionados à força e identificar variáveis associadas a esse fenômeno. Objetivo: Este estudo teve como objetivo investigar a influência dos polimorfismos M235T da enzima conversora da angiotensina-1 (ECA) e do angiotensinogênio (AGT), e da glicemia na força de preensão manual (FPM) em pacientes com DRC com e sem diabetes mellitus (DM). Métodos: Pacientes do sexo masculino $(n=84)$ participaram deste estudo transversal. Os pacientes foram agrupados de acordo com o diagnóstico de DM ou não. Avaliamos a FPM por meio de um dinamômetro e polimorfismo ACE e AGT por reação em cadeia da polimerase. Resultados: Houve diferenças na FPM entre os grupos. As análises de acompanhamento indicaram que uma diferença na distribuição dos alelos do polimorfismo da ECA estava associada à redução da FPM no grupo com DM. A mesma resposta estava presente para AGT. Existia uma correlação negativa entre os níveis de glicose no sangue e FPM $(r=-0,334$ com $p<0,05)$. Discussão: Os presentes dados sugerem que existe uma relação entre capacidade física e baixo controle glicêmico. Conclusão: Nosso estudo demonstrou que os níveis de glicose no sangue estão associados à FPM em pacientes com DRC independente dos polimorfismos ACE I / D e AGT M235T. A presença de DM pode influenciar a retenção da força funcional.

Palavras-chave: Polimorfismo genético; Força muscular; Diabetes Mellitus; Sistema renina-Angiotensina; Envelhecimento; Insuficiência renal crônica.

\section{Resumen}

Antecedentes: los pacientes con enfermedad renal crónica (ERC) suelen presentar comorbilidades como hipertensión y diabetes. Estas condiciones a menudo se asocian con la pérdida de fuerza, que es un fuerte predictor de mortalidad. En este sentido, es razonable investigar marcadores genéticos y fisiológicos que puedan estar relacionados con la fuerza e identificar variables asociadas a este fenómeno. Objetivo: Este estudio tuvo como objetivo investigar la influencia de los polimorfismos M235T de la enzima convertidora de angiotensina-1 (ECA) y del angiotensinógeno (AGT), y la glucosa en sangre sobre la fuerza de agarre (HGS) para pacientes con ERC con y sin diabetes mellitus (DM). Métodos: En este estudio transversal participaron pacientes del sexo masculino $(n=84)$. Los pacientes se agruparon en función del diagnóstico de DM o no. Evaluamos HGS usando un dinamómetro y polimorfismo ACE y AGT por reacción en cadena de la polimerasa. Resultados: Hubo diferencias en HGS entre los grupos. Los análisis de seguimiento indicaron que una diferencia en la distribución de los alelos del polimorfismo de la ECA se asoció con la reducción de HGS en el grupo de DM. La misma respuesta estuvo presente para AGT. Existió una correlación negativa entre los niveles de glucosa en sangre y HGS $(r=-0,334$ con $p<0,05)$. Discusión: Los datos actuales sugieren que existe una relación entre la capacidad física y un mal control glucémico. Conclusión: Nuestro estudio demostró que los niveles de glucosa en 
sangre están asociados con HGS en pacientes con ERC independientemente de los polimorfismos ACE I / D y AGT M235T. La presencia de DM puede influir en la retención de la fuerza funcional.

Palabras clave: Polimorfismo genético; Fuerza muscular; Diabetes Mellitus; Sistema renina-Angiotensina; Envejecimiento; Insuficiência renal crónica.

\section{Introduction}

There is a high incidence of chronic kidney disease (CKD) worldwide, constituting substantial economic burden to the public health system (Levey and Coresh 2012). Patients with CKD tend to present with poor quality of life, typically associated with muscle wasting and impaired muscle strength (Johansen et al. 2003). The assessment of handgrip strength is a generally accepted, low risk assessment of overall strength. This marker is used as an independent predictor of mortality in CKD patients (Chang et al. 2011). Risk for mortality only worsens as CKD progresses to end-stage renal disease (ESRD) (Stenvinkel et al. 2015). Unfortunately, CKD is often accompanied by comorbidities such as diabetes and hypertension.

Diabetes mellitus (DM) is a disease categorized by dysfunctional metabolism of sugars. DM can affect neural tissue (neuropathic diabetes), vasculature walls, and potentially explain a gradual decrease of muscle strength in patients with CKD and DM (Andersen et al. 1996)-(Hasheminejad et al. 2016). Investigators are currently evaluating physiological pathways that can explain the connection between CKD, comorbidities, and patient health and function.

Renin-Angiotensin System (RAS) is a main physiological pathway that regulates blood pressure through vascular tone, electrolyte balance, renal homeostasis, and fluid volume. Angiotensin-1 converting enzyme (ACE) is a critical component of the RAS, maintaining blood pressure by causing vasoconstriction and controlling fluid volume (Charbonneau et al. 2008). ACE enzyme concentration and activity could regulate the energetic homeostasis through modulation of this system (Charbonneau et al. 2008).

The ACE gene is known to contain a polymorphisms consisting of an insertion (I)/ deletion (D) and deletion/deletion (D/D) genotypes. While it is unclear how these genotypes affect those with CKD, the D/D combination was associated with greater muscle strength after strength training when compared to others ACE genotypes in healthy populations (Erskine et al. 2014). Furthermore, it was observed that the T/T genotype, from angiotensinogen AGT M235T polymorphism (rs699; also related to RAS), is prominent in competitive power sports athletes when compared to endurance athletes and controls (Zarebska et al. 2013). If these genetic factors are affected by chronic disease, we could possibly explain strength changes associated with CKD and/or DM.

This study aimed to investigate how ACE I/D, AGT M235T polymorphisms, and blood glucose relate to handgrip strength (HGS) of CKD patients with and without DM.

\section{Methodology}

This is a descriptive and analytical cross-sectional study (Pereira et al., 2018). Approved by the Ethics Committee of the Federal University of São Paulo - UNIFESP (no. 08856012.6.0000.5505). We invited patients from the Nephrology Integrated Center (CINE) (Guarulhos, São Paulo, Brazil) to participate in the study. A convenience sample of 84 male patients (aged 18-70 years) volunteered and were eligible. All volunteers signed the approved informed consent before the data were collected. Inclusion criteria was set to enroll patients who had completed at least three months of hemodialysis (HD) treatment. Patients with any abnormalities of the upper extremities, acquired immunodeficiency syndrome, hepatitis $\mathrm{C}$ were excluded, as well as those who were hospitalized during the study or had recently undergone surgery. Participants were assigned to the DM or non-DM group based on presence of diagnosed DM. HGS and salivary samples for genomic DNA extraction were all collected before the patients' HD treatment. 


\subsection{ACE and AGT polymorphism genotyping}

All participants were genotyped for the presence of insertion alleles (I) or deletion (D) to I/D ACE polymorphism and M235 allele (M) or T235 (T) to M235T of AGT polymorphism. Therefore, the DM (with diabetes mellitus) and non-DM (without diabetes mellitus) groups were stratified according to the polymorphism genotype (homozygotes I/I and D/D; heterozygotes I/D; homozygotes $\mathrm{T} / \mathrm{T}$ and $\mathrm{M} / \mathrm{M}$; heterozygotes $\mathrm{M} / \mathrm{T}$ ).

Blood samples were obtained from all subjects in vacutainer tubes (BD Biosciences, Franklin Lakes, NJ). Genomic DNA was extracted from peripheral blood leucocytes using ChargeSwitch dDNA Blood Kits (Invitrogen, São Paulo, Brazil). ACE ID genotype was determined by PCR using a published 3-primer method that included an I-specific oligonucleotide that produce unambigous results for the ACE genotype. Genotyping for the identification of the AGT were performed using fluorescence-based TaqMan® SNP Genotyping Assays (Applied Biosystems, Foster City, CA, USA). Allele specific probes and flanking primer sets were used along with a pre-made PCR master mix containing ampliTaq DNA polymerase Gold (Applied Biosystems, Foster City, CA, USA) in a reaction volume of $20 \mu \mathrm{l}$. PCR consisted of a 10 min heat activation step $\left(95^{\circ} \mathrm{C}\right)$ followed by 50 cycles of $15 \mathrm{~s}$ at $95^{\circ} \mathrm{C}$ and $1 \mathrm{~min}$ at $60^{\circ} \mathrm{C}$. Amplification was performed in PCR thermocycler, Real Time ABI 7500 (Applied Biosystems).

\subsection{Polymerase Chain Reaction (PCR)}

Genotyping of alleles I/D polymorphism was performed according to Almeida SS protocol (Almeida et al. 2012). The genotyping of alleles of the M235T AGT polymorphism was conducted using a 2-primer system ('primers') specific to the sequence where polymorphism occurs in the gene to amplify them and classify homozygous MM or TT individuals or heterozygous for AGT MT. A third primer was used for angiotensinogen gene.

The sequences of primers were: M235 5'-GTTCATGACAGCGCAGGCTGTTTGGAACCTGACCTCTGGCTGCAT3'; T235 5'-GATGGAAGACTGGCTGCTCCCAGAC-3' and Int2 5'- AGCAGAGAGGTTTGCCTTACCT-3'.

The reagents used for reaction and protocol followed the manufacturer's recommendations GoTaq ${ }^{\circledR}$ Green Master Mix (Promega ${ }^{\circledR}$, Madison, WI, EUA). The PCR results were submitted to electrophoresis on agarose gel and the fragments observed in the ultraviolet light (U.V.).

\subsection{Handgrip stregth test}

Fourty-eigth hour before the test, a familiarization was performed with all the patients. After that, participants completed three trials using a handgrip dynamometer (Jamar Hydraulic Hand Dynamometer 5030 J1, Patterson Medical, Bolingbrook, IL, USA). Participants were seated in a chair and informed to not rest on the back or arms of the chair. With the dominant hand and the thumb facing up (neutral grip), the participant maximally squeezed the dynamometer with their fingers for 4 seconds (Schlussel et al. 2008). Participants were given at least one-minute rest between tries. The highest value was recorded and noted as the maximal voluntary isometric contraction (MVIC) in kilograms of force (kgf). The same researcher instructed and supervised all tests.

\subsection{Statistical analysis}

Differences between groups were assessed using t Student test for comparison between the study groups. One-way analysis of variance (ANOVA), with pairwise Bonferroni post hoc tests were employed for assessments with more than two independent variables. Pearson's correlations were conducted to evaluate associations between variables. A p-value of less than 0.05 was considered significant. Data analyses were performed using Prism® 6.0 (GraphPad® Software, San Diego, USA). Results are presented as mean \pm standard deviation. 


\section{Results and Discussion}

Table 1 presents the baseline characteristics of the patients. There were no statistical differences groups except for blood glucose $(\mathrm{p}<0.05)$. It was observed that the DM group has lower HGS scores when compared to the non-DM group. The mean of the non-DM group was $31.6 \pm 8.9 \mathrm{Kgf}$ and the DM group was $25.4 \pm 6.9 \mathrm{Kgf}(\mathrm{p}<0.05)$. Data are visually presented in Figure 1.

Table 1. Baseline characteristics. Data presented as mean \pm SD.

\begin{tabular}{lcc}
\hline Variable & Non-DM $(\mathbf{n}=\mathbf{4 5})$ & DM $(\mathbf{n = 2 8})$ \\
\hline Age (years) & $52.8 \pm 2.0$ & $52.4 \pm 2.4$ \\
Dialysis duration (months) & $39.45 \pm 5.3$ & $32.5 \pm 5.1$ \\
Dry Weight $(\mathrm{kg})$ & $74.1 \pm 2.4$ & $76.1 \pm 2.8$ \\
BMI $\left(\mathrm{kg} / \mathrm{m}^{2}\right)$ & $25.7 \pm 0.8$ & $25.2 \pm 0.8$ \\
GFR $\left(\mathrm{mL} / \mathrm{min} / 173 \mathrm{~m}^{2}\right)$ & $6.7 \pm 0.6$ & $6.7 \pm 0.6$ \\
Blood glucose $(\mathrm{mg} / \mathrm{dL})$ & $101.8 \pm 5.8$ & $200 \pm 28^{\mathrm{a}}$ \\
\hline
\end{tabular}

Non-DM = non-diabetic; $\mathrm{DM}=$ diabetic; $\mathrm{BMI}=$ body mass index; GFR = glomerular filtration rate; ${ }^{\mathrm{a}} p<0,05$. Source: Authors.

Figure 1. Handgrip strength between Non-DM (without diabetes mellitus) and DM (with diabetes mellitus) groups.

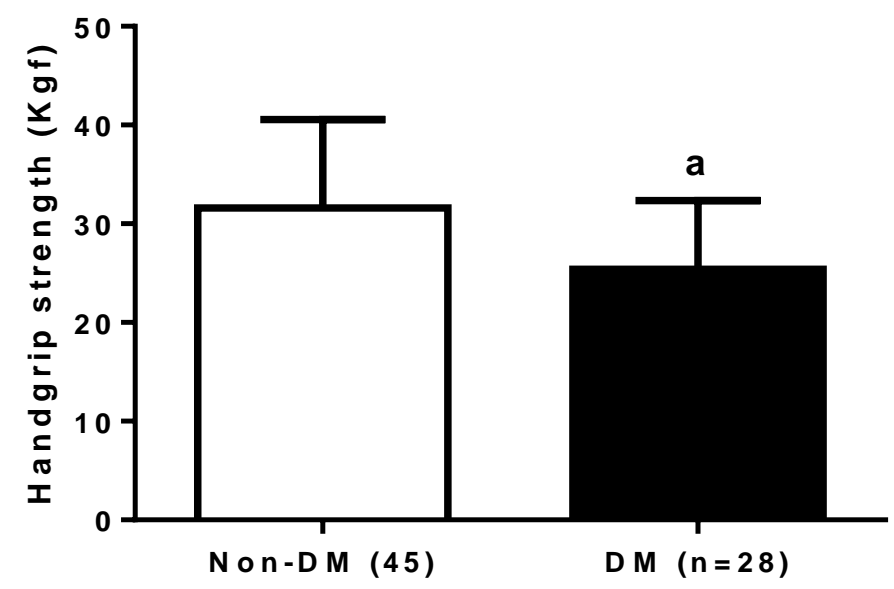

Data presented as mean \pm SD. Handgrip strength between Non-DM (without diabetes mellitus) and DM (with diabetes mellitus) groups. a $\mathrm{p}<$ 0.05 vs. Non-DM. Source: Authors.

The group formed by heterozygotes I/D showed no difference between the non-DM group and DM in ACE polymorphism ( $p>0.05$ ). When evaluating HGS, there was a difference in ACE polymorphism between genotypes I/I for nonDM $(34.5 \pm 9.7 \mathrm{Kgf})$ and those with DM $(24.5 \pm 7.3 \mathrm{Kgf} ; \mathrm{p}<0.05)$. Similarly, D/D differed for those without $(33.5 \pm 8.5 \mathrm{Kgf})$ DM and those with DM $(23.6 \pm 8.1 \mathrm{Kgf} ; \mathrm{p}<0.05)$ (Figure 2a).

For groups separated by AGT M235T polymorphism, the results showed that homozygous groups MM and TT does not differ in HGS among non-DM and DM groups. Only individuals classified as heterozygotes (MT) showed statistical difference, without (32.4 $\pm 8.7 \mathrm{Kgf})$ and with $(24.2 \pm 5.0 \mathrm{Kgf} ; \mathrm{p}<0.05)$ DM (Figure 2). 
Figure 2. Handgrip strength between ACE polymorphism and between angiotensinogen polymorphism in non-DM and DM groups.

a)

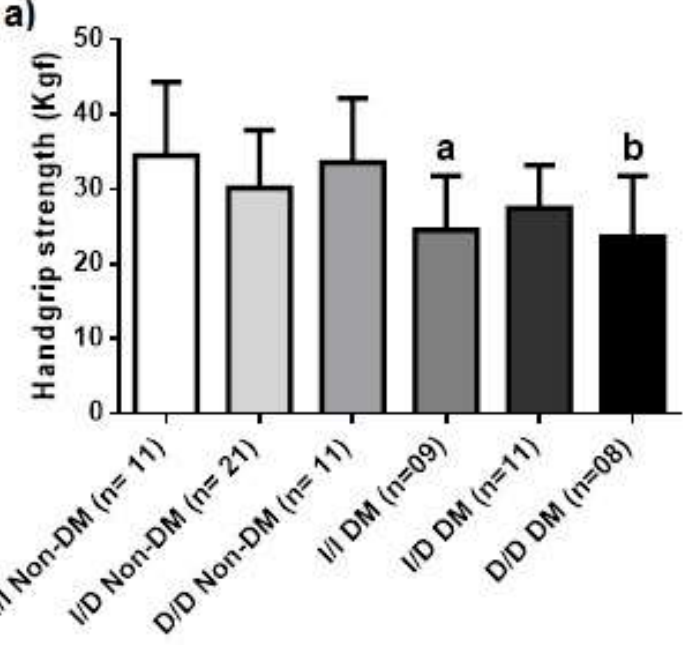

b)

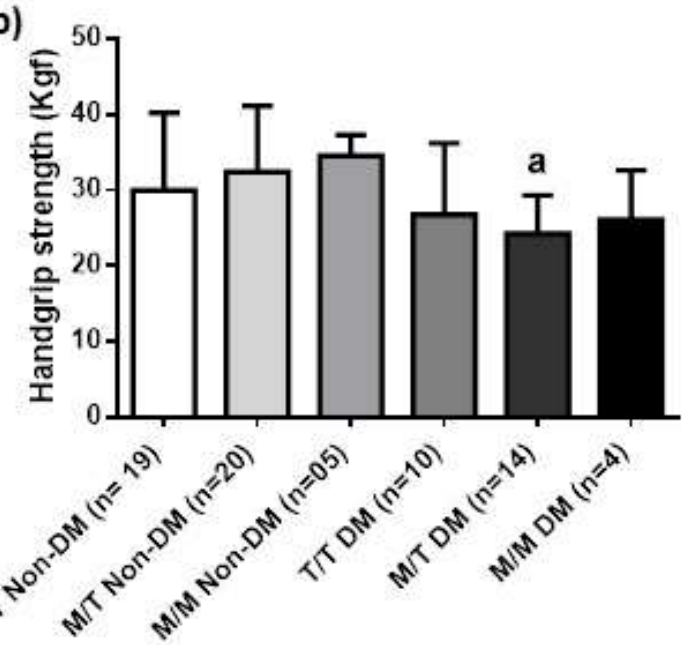

Data presented as mean \pm SD. a) Handgrip strength between ACE polymorphism in non-DM and DM groups. a $p<0.05$ vs. I/I Non-DM; b $p$ $<0.05$ vs. D/D Non-DM. b) Handgrip strength between angiotensinogen polymorphism in non-DM and DM groups. a $\mathrm{p}<0.05 \mathrm{vs}$. M/T NonDM. ACE, angiotensin converting enzyme; DM diabetes Mellitus. Source: Authors.

HGS was lower in groups with DM was observed (I DM 25.6 $\pm 6.6 \mathrm{Kgf}$ and D DM $25.1 \pm 7.2 \mathrm{kgf}$ ) compared to those in the non-DM groups (I Non-DM $32.4 \pm 8.8 \mathrm{kgf}$ and D Non-DM $31.9 \pm 8.1 \mathrm{kgf} ; \mathrm{p}<0.05$ ) when considering the ACE polymorphism allele (Figure 3). The coefficient of variation between the tests was 6.3\% Similarly, we observed the same reduction in HGS when involving the AGT alleles in the DM group (T DM 25.7 $\pm 7.7 \mathrm{Kgf}$ and M DM 24.9 $\pm 5.3 \mathrm{kgf}$ ), compared to non-DM (T non-DM $30.8 \pm 9.6 \mathrm{kgf}$ and M non-DM $33.1 \pm 7.2 \mathrm{kgf} ; \mathrm{p}<0.05$ ) (Figure 3 ).

Figure 3. Handgrip strength between ACE allele in Non-DM and DM groups (with diabetes mellitus).

a)

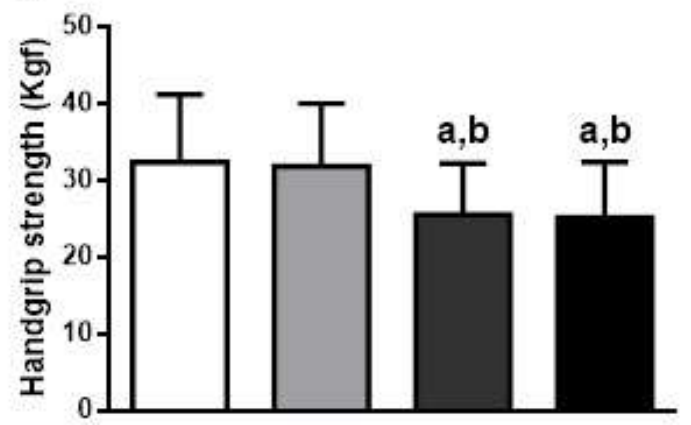

b)

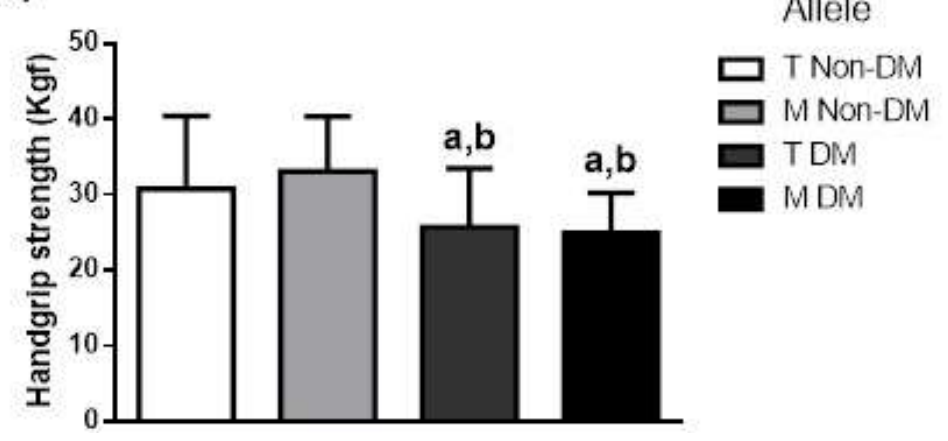

Data presented as mean \pm SD. a) Handgrip strength between ACE allele in Non-DM and DM groups (with diabetes $m e l l i t u s$ ). ${ }^{\mathrm{a}} p<0.05$ vs. T non-DM. ${ }^{\mathrm{b}} p<0.05$ vs. M non-DM. b) Handgrip strength between ACE allele in non-DM and DM groups. ${ }^{\mathrm{a}} p<0.05$ vs. T non-DM. ${ }^{\mathrm{b}} p<0.05$ vs. M non-DM. DM diabetes Mellitus. Source: Authors.

There was a negative correlation of blood glucose concentration with HGS $(r=-0.334, \mathrm{p}<0.05)$ (Figure 4). We also observed that patients with HGS below $28 \mathrm{Kgf}$ presented with significantly higher blood glucose than those with HGS greater than $28 \mathrm{kgf}$ (Figure 5).

Figure 4. Data presented correlation between glycemia and handgrip strength in patients with CKD. CKD, chronic kidney disease. 


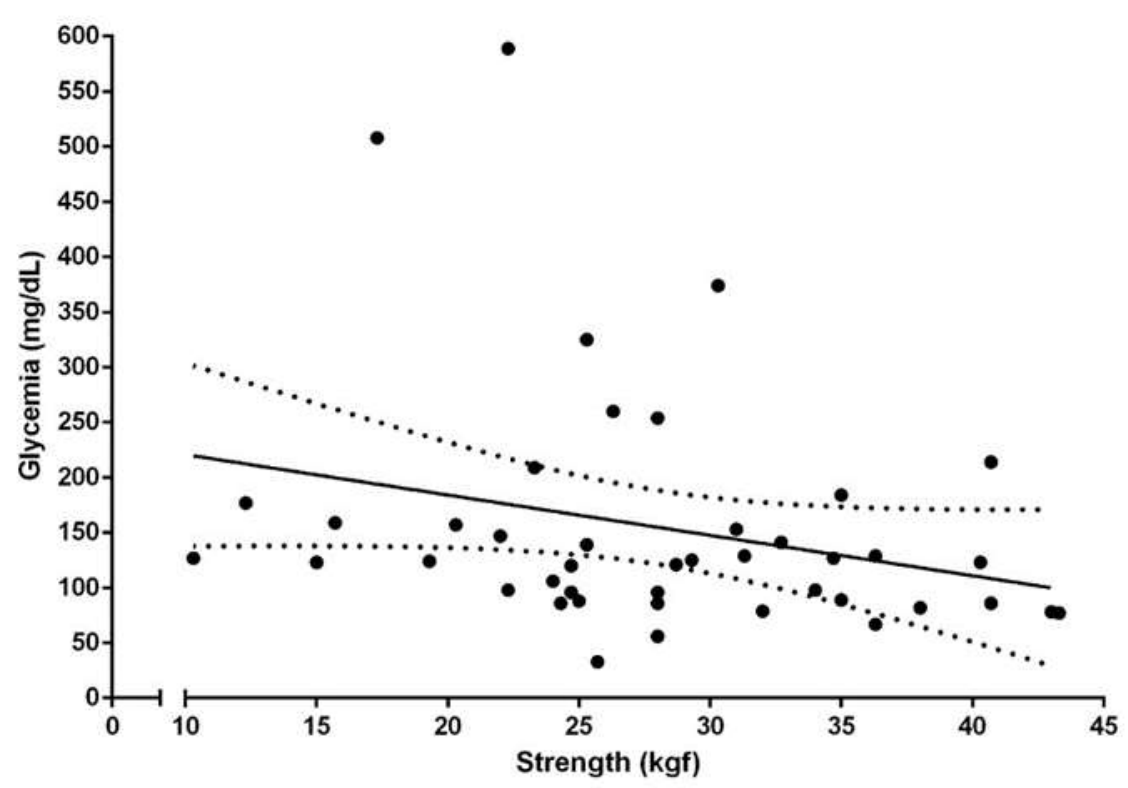

Source: Authors.

Figure 5. Association between blood glucose and HGS (hand grip strength) in patients with chronic kidney disease separated in low fitness $(<28 \mathrm{kgf})$ or high fitness (>28kgf). Dots represent outliers.

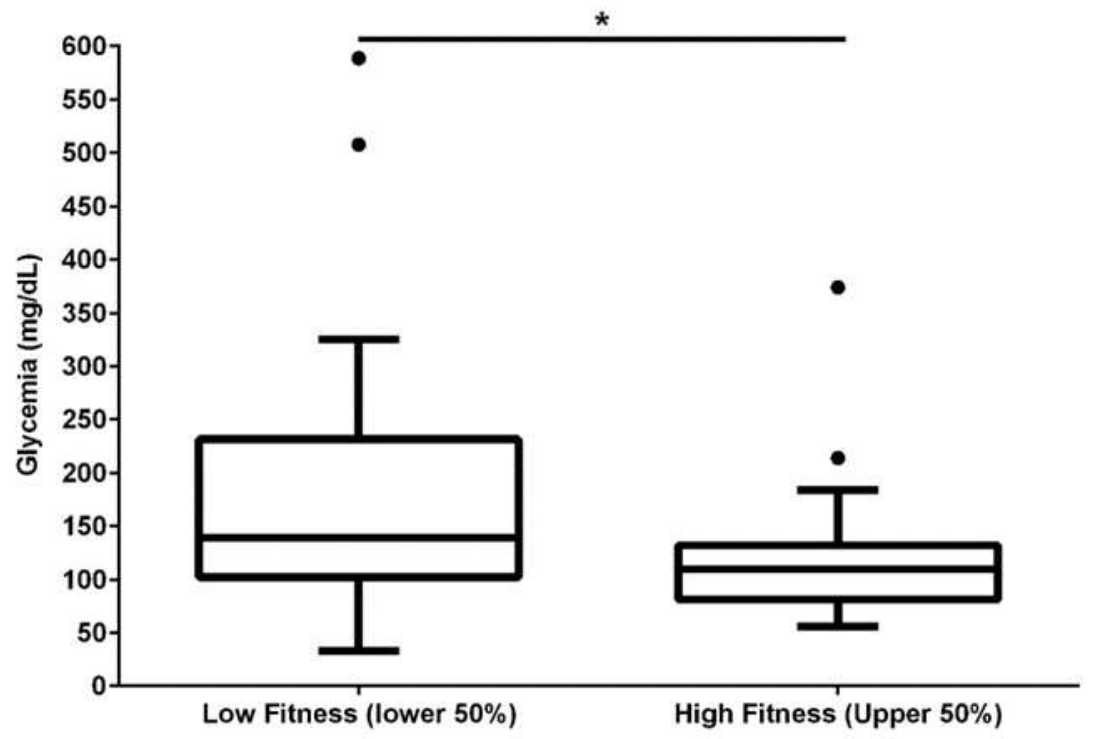

Source: Authors.

The intent of this investigation was to evaluate HGS, CKD, and the effect of DM. The principle finding of our study was that ACE blood glucose is more related to loss of HGS than alleles ACE and AGT M235T polymorphisms in patients with CKD (Chang et al. 2011). Presently, CKD patients with DM averaged HGS at 25 Kgf, approximately $10 \%$ lower than those without DM. It was previously demonstrated (Chang et al. 2011) that values lower than $24.65 \mathrm{Kgf}$ increases the mortality rate in $47.1 \%$ for those with CKD.

It is well known the importance of muscle strength to CKD patients (Stenvinkel et al. 2015). The present study builds on this body of knowledge by showing a relationship between reduced physical capacity and poor glycemic control. This 
conclusion is founded in the negative correlation between HGS and blood glucose levels. Few studies have reported a direct relation between HGS and blood glucose levels (Valensi et al. 1995; Wallymahmed et al. 2007); this is the first to confirm this correlation in the population at ESRD.

Expense of clinical assessments associated with chronic diseases is on the rise. It would be advantageous to identify more practical, inexpensive modalities (like HGS) with potential to monitor patients' response to HD. To support simple assessments, breakthroughs in the field of genetics are occurring regularly. However, there is still a need for more research to identify relationships between specific gene phenotypes with various chronic conditions, noting that what is available now often conflicts (Eisenberger et al. 2015).

Blood glucose monitoring through HD could be an important aim for estimating skeletal muscle function as we found an inverse relationship between the variables. If there is a causal relationship, maintaining blood glucose may prevent muscle wasting and minimize mortality risk of patients with CKD and DM. The simple addition of HGS assessments could be included in repeated evaluations in CKD patients, especially in those with DM, as they are statistically at a greater risk for mortality. We could argue the link between blood glucose and HGS is the greater metabolism of carbohydrate in those with higher proportions of lean body mass (Giusti et al. 1996). Because lean body mass is positively associated with HGS (Charlton et al. 2015), it would benefit CKD patients completing HD to participate in strength training activities to prevent muscle strength.

Overactive RAS leads to ACE and AGT M235T polymorphisms are related to comorbidities like hypertension and cardiovascular disease, often accompanying CKD (Aucella et al. 2000; Lovati et al. 2001; Shanmuganathan et al. 2015; Wang and Pan 2014). In CKD, the I/D polymorphism of ACE is prognostic to declined kidney disease and opposer to the genotype D/D. I/D is associated with elevated levels of proteinuria (VAN DIJK et al. 1999), advancing ESRD independent of age (Baboolal et al. 1997) or the presence of hypertension (Pérez-Oller et al. 1999). Additionally, the polymorphism of the AGT M235T has the T allele and negative agent, facilitating the increase of proteinuria (Baboolal et al. 1997; Pei et al. 1997), a negative predictive of ESRD (Anbazhagan et al. 2009; Frimat et al. 2000; Zhou et al. 2013) and left ventricular hypertrophy (Wang et al. 2003). In $\mathrm{CKD}$, the $\mathrm{T}$ allele negatively impacts patient survival (Alves et al. 2014) and is also described as being relevant in the heredity of diabetic nephropathy (Rogus et al. 1998).

However, contrary to our expectations, neither ACE or AGT M235T polymorphisms influenced HGS in CKD patients (DM or non-DM). Therefore, the loss of strength in CKD patients must be resultant of non-assessed mechanisms, beyond these polymorphisms. Although previous evidences associated D allele of ACE polymorphism (Charbonneau et al. 2008; Erskine et al. 2014) and T allele of AGT M235T polymorphism with strength sports (Zarebska et al. 2013), it appears their influence is relegated to athletes.

The present data identified a difference in muscle strength between participants with and without DM, partially explained by the allele polymorphism in ACE and AGT. We expected no differences between the D/D for those with DM and non-DM groups. This response may be explained through literature reporting that this genotype (D/D) is responsible for increasing muscle strength following resistance training when compared to genotype I/I and I/D in health subjects (Folland et al. 2000). Unfortunately, there is still little known about the role of polymorphism I/D of ACE in maintaining lean body mass or strength for patients with CKD. We may ultimately conclude that this genotype may not influence HGS or muscle phenotype for those at risk for muscle wasting (Garatachea et al. 2012).

The present study may be improved by addressing the limitations identified by the authors. The current investigation was limited to a sample of convenience, and ultimately a smaller than optimal sample size. The population being studied is likely the largest hurdle for future research (under dialysis treatment and willing to consent to genome testing). Additionally, we did not dose insulin or perform HOMA calculation, but we used a low-cost and convenient method which is fasting glucose. Despite the small sample and glucose assessment, our study brings robust results and paves the way for future studies to test other metrics 
related to physical fitness and the influence of the genetic load in the process in ESRD.

\section{Conclusion}

In conclusion, the present study demonstrated that higher blood glucose levels are associated to lower HGS of patients with CKD independent of ACE and AGT M235T polymorphisms.

\section{Acknowledgments}

We thank the Integrated Center of Nephrology, Guarulhos, São Paulo, Brazil for the assistance in the project.

\section{References}

Almeida, S., et al. (2012) Carbamazepine inhibits angiotensin I-converting enzyme, linking it to the pathogenesis of temporal lobe epilepsy Translational psychiatry 2:e93.

Alves, M., Silva, N. A. S., Salis, L. H. A., Pereira, B. B., Godoy, P. H., Nascimento, E. M., \& Oliveira, J. M. F. (2014) Survival and Predictive Factors of Lethality in Hemodyalisis: D/I Polymorphism of The Angiotensin I-Converting Enzyme and of the Angiotensinogen M235T Genes Arquivos brasileiros de cardiologia 103:209-219.

Anbazhagan, K., Sampathkumar, K., Ramakrishnan, M., Gomathi, P., Gomathi, S., \& Selvam, G. S. (2009) Analysis of polymorphism in renin angiotensin system and other related genes in South Indian chronic kidney disease patients Clinica Chimica Acta 406:108-112.

Andersen, H., Poulsen, P. L., Mogensen, C. E., \& Jakobsen, J. (1996) Isokinetic muscle strength in long-term IDDM patients in relation to diabetic complications Diabetes 45:440-445.

Aucella, F. et al. (2000) Polymorphism of the angiotensin-converting enzyme gene in end-stage renal failure patients Nephron 85:54-59.

Baboolal, K., Ravine, D., Daniels, J., Williams, N., Holmans, P., Coles, G. A., \& Williams, J. D. (1997) Association of the angiotensin I converting enzyme gene deletion polymorphism with early onset of ESRF in PKD1 adult polycystic kidney disease Kidney international 52:607-613.

Chang, Y. T., et al. (2011) Handgrip strength is an independent predictor of renal outcomes in patients with chronic kidney diseases Nephrology, dialysis, transplantation : official publication of the European Dialysis and Transplant Association - European Renal Association 26:3588-3595 10.1093/ndt/gfr013.

Charbonneau, D. E., Hanson, E. D., Ludlow, A. T., Delmonico, M. J., Hurley, B. F., \& Roth, S. M. (2008) ACE genotype and the muscle hypertrophic and strength responses to strength training Medicine and science in sports and exercise 40:677.

Charlton, K., et al. (2015) Lean Body Mass Associated with Upper Body Strength in Healthy Older Adults While Higher Body Fat Limits Lower Extremity Performance and Endurance Nutrients 7:7126-7142 doi:10.3390/nu7095327.

Eisenberger, T., et al. (2015) An efficient and comprehensive strategy for genetic diagnostics of polycystic kidney disease PloS one 10:e0116680.

Erskine, R., Williams, A., Jones, D., Stewart, C., \& Degens, H. (2014) The individual and combined influence of ACE and ACTN3 genotypes on muscle phenotypes before and after strength training Scandinavian journal of medicine \& science in sports 24:642-648.

Folland, J., Leach, B., Little, T., Hawker, K., Myerson, S., Montgomery, H., \& Jones, D. (2000) Angiotensin-converting enzyme genotype affects the response of human skeletal muscle to functional overload Experimental Physiology 85:575-579.

Frimat, L., Philippe, C., Maghakian, M-N., Jonveaux, P., De Ligny, B. H., Guillemin, F., \& Kessler, M. (2000) Polymorphism of Angiotensin Converting.

Enzyme, Angiotensinogen, and Angiotensin II Type 1 Receptor Genes and End-Stage Renal Failure in IgA Nephropathy IGARAS-A Study of 274 Men Journal of the American Society of Nephrology 11:2062-2067.

Garatachea, N. et al. (2012) Single and combined influence of ACE and ACTN3 genotypes on muscle phenotypes in octogenarians European journal of applied physiology 112:2409-2420.

Giusti, V., Schneiter, P., Thiebaud, D., Landry, M., Burckhardt, P., Jequier, E., \& Tappy, L. (1996) Influences of body weight, body composition, and substrate oxidation rate on resting postabsorptive glucose production and gluconeogenesis Int J Obes Relat Metab Disord 20:842-847.

Hasheminejad, N., Namdari, M., Mahmoodi, M. R., Bahrampour, A., \& Azmandian, J. (2016) Association of Handgrip Strength With Malnutrition-Inflammation Score as an Assessment of Nutritional Status in Hemodialysis Patients Iran J Kidney Dis 10:30-35.

Johansen, K. L., Shubert, T., Doyle, J., Soher, B., Sakkas, G. K., \& Kent-Braun, J. A. (2003) Muscle atrophy in patients receiving hemodialysis: effects on muscle strength, muscle quality, and physical function Kidney international 63:291-297 doi:10.1046/j.1523-1755.2003.00704.x.

Levey, A. S., \& Coresh, J. (2012) Chronic kidney disease Lancet 379:165-180. 10.1016/S0140-6736(11)60178-5.

Lovati, E., Richard, A., Frey, B. M., Frey, F. J., \& Ferrari, P. (2001) Genetic polymorphisms of the renin-angiotensin-aldosterone system in end-stage renal disease Kidney international 60:46-54. 
Pei, Y., Scholey, J., Thai, K., Suzuki, M., \& Cattran, D. (1997) Association of angiotensinogen gene T235 variant with progression of immunoglobin A nephropathy in Caucasian patients Journal of Clinical Investigation 100:814.

Pereira, A. S., Shitsuka, D. M., Parreira, F. J., \& Shitsuka, R. (2018). Metodologia da pesquisa científica. UFSM. https://repositorio. ufsm. br/bitstream/handle/1/15824/Lic_Computacao_Metodologia-Pesquisa-Cientifica.pdf.

Pérez-Oller, L., Torra, R., Badenas, C., Milà, M., \& Darnell, A. (1999) Influence of the ACE gene polymorphism in the progression of renal failure in autosomal dominant polycystic kidney disease American journal of kidney diseases 34:273-278.

Rogus, J. J., Moczulski, D., Freire, M. B. S., Yang, Y., Warram, J. H., \& Krolewski, A. S. (1998) Diabetic nephropathy is associated with AGT polymorphism T235 results of a family-based study Hypertension 31:627-631.

Schlussel, M. M., dos Anjos, L. A., de Vasconcellos, M. T., \& Kac, G. (2008) Reference values of handgrip dynamometry of healthy adults: a population-based study Clin Nutr 27:601-607 doi:10.1016/j.clnu.2008.04.004.

Shanmuganathan, R., Kumaresan, R., \& Giri, P. (2015) Prevalence of angiotensin converting enzyme (ACE) gene insertion/deletion polymorphism in South Indian population with hypertension and chronic kidney disease Journal of postgraduate medicine 61:230.

Stenvinkel, P., Carrero, J. J., von Walden, F., Ikizler, T. A., \& Nader, G. A. (2015) Muscle wasting in end-stage renal disease promulgates premature death: established, emerging and potential novel treatment strategies Nephrology, dialysis, transplantation: official publication of the European Dialysis and Transplant Association - European Renal Association 10.1093/ndt/gfv122.

Valensi, P., Thi, B., Lormeau, B., Paries, J., \& Attali, J. (1995) Cardiac autonomic function in obese patients International journal of obesity and related metabolic disorders: journal of the International Association for the Study of Obesity 19:113-118.

Van Dijk, M. A., Peters, D. J., Breuning, M. H., \& Chang, P. C. (1999) The angiotensin-converting enzyme genotype and microalbuminuria in autosomal dominant polycystic kidney disease Journal of the American Society of Nephrology 10:1916-1920.

Wallymahmed, M., Morgan, C., Gill, G., \& MacFarlane, I. (2007) Aerobic fitness and hand grip strength in Type 1 diabetes: relationship to glycaemic control and body composition Diabetic Medicine 24:1296-1299.

Wang, A. Y-M., Chan, J. C-N., Wang, M., Poon, E., Lui, S-F., Li, P. K-T., \& Sanderson, J. (2003) Cardiac hypertrophy and remodeling in relation to ACE and angiotensinogen genes genotypes in Chinese dialysis patients Kidney international 63:1899-1907.

Wang, Y-J., \& Pan, Y. (2014) The M235T polymorphism in the angiotensinogen gene and myocardial infarction risk: A meta-analysis Journal of ReninAngiotensin-Aldosterone System 15:294-300.

Zarebska, A., et al. (2013) Association of rs699 (M235T) polymorphism in the AGT gene with power but not endurance athlete status The Journal of Strength \& Conditioning Research 27:2898-2903.

Zhou, T-B., Yin, S-S., \& Qin, Y-H. (2013) Association of angiotensinogen M235T gene polymorphism with end-stage renal disease risk: a meta-analysis Molecular biology reports 40:765-772. 